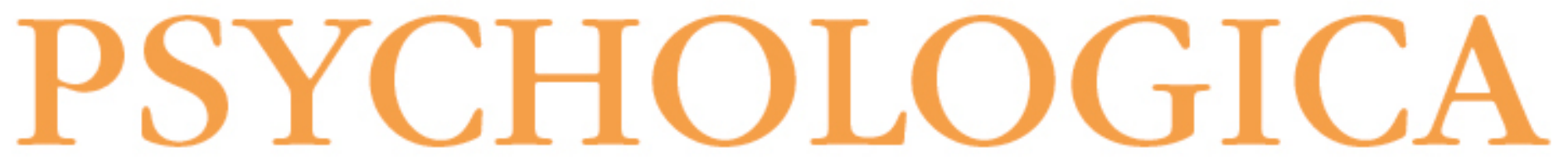

\title{
Expressive and creative writing in the therapeutic context: from the different concepts to the development of writing therapy programs
}

Autor(es): $\quad$ Costa, Ana Catarina; Abreu, Manuel Viegas

Publicado por: Imprensa da Universidade de Coimbra

URL

persistente: $\quad$ URI:http://hdl.handle.net/10316.2/43571

DOI: $\quad$ DOI:https://doi.org/10.14195/1647-8606_61-1_4

Accessed : $\quad$ 26-Apr-2023 09:25:40

A navegação consulta e descarregamento dos títulos inseridos nas Bibliotecas Digitais UC Digitalis, UC Pombalina e UC Impactum, pressupõem a aceitação plena e sem reservas dos Termos e Condições de Uso destas Bibliotecas Digitais, disponíveis em https://digitalis.uc.pt/pt-pt/termos.

Conforme exposto nos referidos Termos e Condições de Uso, o descarregamento de títulos de acesso restrito requer uma licença válida de autorização devendo o utilizador aceder ao(s) documento(s) a partir de um endereço de IP da instituição detentora da supramencionada licença.

Ao utilizador é apenas permitido o descarregamento para uso pessoal, pelo que o emprego do(s) título(s) descarregado(s) para outro fim, designadamente comercial, carece de autorização do respetivo autor ou editor da obra.

Na medida em que todas as obras da UC Digitalis se encontram protegidas pelo Código do Direito de Autor e Direitos Conexos e demais legislação aplicável, toda a cópia, parcial ou total, deste documento, nos casos em que é legalmente admitida, deverá conter ou fazer-se acompanhar por este aviso.

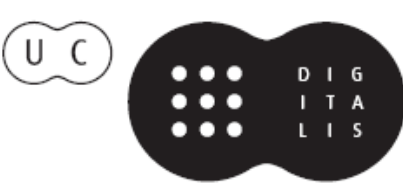


VOLUME

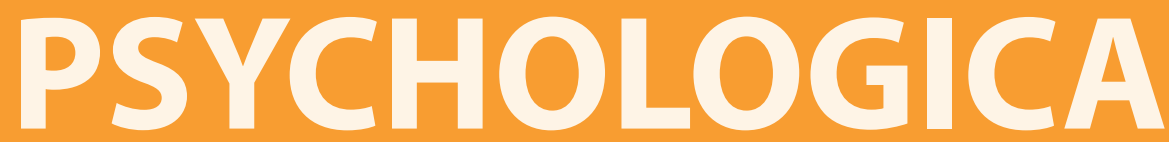

IMPRENSA DA UNIVERSIDADE DE COIMBRA

COIMBRA UNIVERSITY PRESS

FACULDADE DE PSICOLOGIA E DE CIÊNCIAS

DA EDUCAÇÃO DA UNIVERSIDADE DE COIMBRA 


\title{
Expressive and creative writing in the therapeutic context: From the different concepts to the development of writing therapy programs
}

\author{
Ana Catarina Costa ${ }^{1}$ e Manuel Viegas Abreu$^{2}$
}

\begin{abstract}
One of the main aims of this scoping selective review is to clarify the differences between expressive and creative writing in the mental health context, not only at a conceptual level but also regarding its therapeutic effects. The other one is to identify the more efficient ways to develop therapeutic creative writing programs for a clinical population. Considering these specific aims, we employed a selective review on the writing therapeutic literature. We found that, although expressive writing is clearly defined and its benefits on mental health empirically well established, creative writing lacks a consistent conceptualization in clinical settings. Similarly, we reported several studies focusing in the therapeutic benefits of poetry, but other writings genres receive much less attention and are even more insufficiently defined. Since some studies support the idea that giving a significant content to a text is more beneficial, and considering that writing creatively offers new perspectives and meanings to the information, we propose that the development of creative writing programs should be tried. Aiming to develop such programs in the future, we give some suggestions based on already studied expressive writing methods.
\end{abstract}

Keywords: expressive writing; creative writing; self-expression; therapeutic writing; poetry therapy

1 Faculdade de Psicologia e Ciências da Educação da Universidade de Coimbra. E-mail: catarinacosta3@gmail.com

2 Faculdade de Psicologia e Ciências da Educação da Universidade de Coimbra. E-mail: abreu@fpce.uc.pt 
A escrita expressiva e criativa no contexto terapêutico: Dos diferentes conceitos ao desenvolvimento de programas de escrita terapêutica

\section{Resumo}

Um dos principais objectivos desta revisão selectiva da literatura no campo da escrita terapêutica consiste em clarificar as diferenças entre escrita expressiva e escrita criativa no contexto da saúde mental. Um outro objectivo visa identificar os procedimentos mais eficazes para desenvolver programas de escrita criativa para uma população clínica. Considerando estes objectivos específicos, utilizámos uma revisão selectiva focada no campo específico do estudo sobre escrita terapêutica. Verificámos que apesar de a escrita expressiva se encontrar claramente definida e os seus benefícios na saúde mental terem recebido um extenso suporte empírico, a escrita criativa apresenta lacunas de uma conceptualização consistente no contexto clínico. De forma similar, encontrámos vários estudos focados nos benefícios terapêuticos da poesia; todavia, outros géneros literários recebem muito menos atenção e encontram-se ainda mais insuficientemente definidos. Uma vez que alguns estudos apoiam a ideia de que dar um conteúdo com significado a um texto é mais benéfico, e dado que escrever criativamente implica oferecer novas perspectivas e significados à informação, propomos que o desenvolvimento de programas de escrita criativa deve ser experimentado. Com o objectivo de desenvolver estes programas no futuro, damos algumas sugestões baseadas em métodos de escrita expressiva já estudados.

Palavras-chave: escrita expressiva; escrita criativa; auto-expressão; escrita terapêutica; terapia pela poesia

\section{INTRODUCTION}

\section{The problem and the study's aims}

Expressive writing was a term coined by James W. Pennebaker in the 1980 s and refers to the written expression of thoughts and feelings surrounding upsetting or traumatic events. In the past decades, there has been several empirical experiences that confirmed the benefits of the disclosure of negative emotions through writing (e.g., Baum \& Rude, 2013; Pennebaker, 1997; Spera, Buhrfeind, \& Pennebaker, 1994). Differently, creative writing, implying an artistic and literary proposal in the writ- 
ten expression of emotions, is still not defined as a particular therapy or practice in the context of psychosocial rehabilitation. Its conceptualization is found more commonly in educational and academic settings. Expressive and creative writing are two rather different concepts that appear often side by side in systematic reviews about therapeutic writing (e.g., Nyssen et al., 2016). In this review the aim was to study the differential features of these two therapeutic writing processes and to compare its different benefits in the therapeutic setting in order to establish some developments in the field of writing therapy programs. More specifically we aim to:

- To define, describe and distinguish creative and expressive writing used as therapies in the mental health context;

- To define and distinguish the narrative writing in the context of the Basic Writing Paradigm from creative writing;

- To analyze the best ways to develop therapeutic writing programs for a clinical population.

\section{THE METHODOLOGY}

Following the typology used by Grant and Booth (2009), we conducted a scoping selective review which consisted of a comprehensive and qualitative synthesis of the literature regarding writing as a therapy in the mental health context. The searches were made between June 2014 and October 2016, using the Psych Info and Scopus databases as primary sources and Google as a secondary source. We revised 42 articles with a different temporal framing. The oldest article is from 1978 and the most recent from 2016. The searches were conducted using different combinations of the following keywords which must be presented in the article's title and/or the abstract: expressive writing, creative writing, writing, therapeutic, poetry, therapy, mental health, mental disorders. Some of the articles were found in hand searches through the bibliographic references of the articles found in the databases. Although the selection of information was subjective and lacked explicit criteria for inclusion, we exhaustively looked for articles in academic journals that could help us to answer three broad research questions:

- What are the differences between using expressive and creative writing as a therapy in the mental health context?

- What are the main differences between narrative expressive writing and creative writing in a therapeutic context?

- How can we develop therapeutic writing programs for a clinical population? 


\section{Differences between creative writing and expressive writing}

\subsection{Creative writing: the literature of self-expression}

Creative therapies have been used in addition to medical and pharmacological treatment with people with mental illness to whom psychotherapy is more difficult. According to King, Neilsen, and White (2013), creative activity may serve as a window into the unconscious or as a means for promoting communication among clients, such as children for whom verbal communication alone might be difficult.

Not all the art and creative writing produced by people in psychological treatment are created in a controlled therapeutic environment. The spontaneous production of arts and writing in informal contexts without the presence of a therapist can have also therapeutic benefits but it is much more difficult to assess them. People with mental illness generally benefit from creative approaches that exploit their own idiosyncratic visions of reality and life, instead of rejecting them as incongruent or frantic imagery. For instance, according to Resende (2008), vulnerability to schizophrenia presents certain creative benefits derived from their perceptual, cognitive and personality characteristics. Individuals in the positive spectrum of schizophrenia are more oriented to eccentric behavior, intuitive and magic thought and more openness to experiences with a low level of inhibition. We suggest that creative therapies can potentiate in a positive way these characteristics, giving an esthetical and artistic configuration to the perceptions, thoughts and visions of these people and validate them in a contained way.

Nyssen et al. (2016) conducted a systematic review in order to analyze the effectiveness of emotional disclosure of therapeutic writing interventions in patients with long term conditions. These interventions comprised several writing forms, including creative writing and poetry, but the concluding results were not differentiated for each intervention. The authors found that for individual therapeutic writing, the main mechanisms and contexts were difficult to clarify and it was unclear as to why participants would have wanted to do that or what they would gain from it. For the therapeutic writing done in group, there was not found a standard intervention, on the contrary, the participants engaged in different ways and at different times with the group and the writing activity.

We did not find studies that define and conceptualize creative writing as a particular therapy or creative writing programs in clinical settings. And although we found several studies declaring the benefits of poetry therapy (e.g., Fallahi Koshknab, Asayesh, Qorbani, Fadaei, \& Rahmani Anaraki, 2016; Houlding \& Holland, 1988; Tamura, 2001), this therapy still lacks an explanatory model which 
would be able to regulate the clinical practices and methods and to constitute a basis for improvement.

In educational settings, creative writing usually refers to the production of original compositions focusing self-expression and, hence, it comes close to literary writing. Being more than just plainly reporting feelings, it implies ideally the transcription of those feelings through an original style. Writing creatively would give thus a symbolic or aesthetical meaning of feelings or ideas instead of just a description of them. King et al. (2013) developed a workshop of creative writing but it had similar instructions as expressive writing experiments: participants were asked to engage in telling a story from their lives and commenting on it at the same time. What differed here were the didactic and interactive techniques used by trainers to help the participants to develop their writing skills. The authors concluded that the therapeutic value of creative writing might be most effectively achieved when there was a focus on the processes and techniques of writing, and not just on self-expression. Anyway, regardless of the instructions, writing a life narrative as participants were encouraged to in expressive writing tasks or in these kind of workshops, entails already an implicit transformation of information towards a meaningful structuring. So, there is already a start of the creative process even if it is not orientated to an original composition.

Hence, the concept of creative writing is still not well defined in the therapeutic settings and sometimes different writing activities (storytelling, prose, poetry) are included in the same creative writing approach and not differentiated. For instance, Fair, Connor, Albright, Wise, and Jones (2012) described and evaluated "Teens Out Loud," a creative writing group for adolescents with HIV which included activities like responding to poetry, free writing and story writing. The results suggested that creative writing groups can promote personal growth and decreased isolation of youth living with HIV. But the different methods, characteristics and benefits of each writing activity were not described or assessed.

There is also a lack of studies that assess the benefits of creative literary writing besides poetry. As for poetry therapy, it has been used mainly with people with severe mental illness and its rehabilitation benefits are well documented (Houlding \& Holland, 1988; Mazza \& Hayton, 2013; Tamura, 2001), but it has been also used with non clinical populations (Croom, 2015). In both situations, individuals are stimulated to translate into symbolic texts their own feelings and experiences that are more difficult to express in current verbal language.

In an overview of the state of poetry therapy conducted by Heimes (2011), it was demonstrated that this type of therapy is well established and documented in the United States. Also, Mazza and Hayton (2013) found that poetry therapy is widespread in clinical practice, although little exists in terms of empirical support for 
its use. They also found that, examining the research and practice base of poetry therapy, the terminology has remained a problem and that the literature lacked a systematic investigation of the use of poetry therapy methods with respect to professional discipline, theoretical orientation, client characteristics, problem/disorder, treatment modality and stage of treatment.

Ruddy and Milnes (2005) suggested that art therapy allows the exploration of the patient's inner world in a non-threatening way and the art work offers a buffer to reduce the intensity in the relationship between the therapist and patient. Poetry is an artistic form among others that can be especially helpful in the therapeutic relationship in disturbed patients given their difficulty in intense interactions. According to Miller (1978), during poetry therapy sessions patients often use metaphors in describing their problems, and understanding and using patient symbolism can enhance the therapeutic relationship. In his study, it was concluded that discussing poems helps the patients to identify themselves with the artistic and creative aspects of their personalities, thus enhancing their ego functioning. Besides, poetry cuts through the psychotic person's defenses. Houlding and Holland (1988) also analyzed a poetry writing group in psychiatric inpatients and concluded that it is useful in containing, organizing, and expressing otherwise overwhelming material. The dissemination of written poems allows a form of contact with fellow patients and indicates to clinicians possibilities for treatment. The effectiveness of poetry group therapy on communicational skills of schizophrenic patients was tested recently in Iran by Fallahi Koshknab et al. (2016) in an empirical study, and it was shown that the patients that participated in a poetry group therapy that was held twice a week for 6 weeks showed a significant improvement in those skills in comparison to the patients of the control group.

Moreover, a particular Japanese form of collaborative poetry writing, renku, which consists in writing stanzas that should be linked to previous stanzas, written by other participants, is considered especially helpful when used with people with schizophrenia (Tamura, 2001), who have more difficulties in understanding the meaning of the words in a context and in communicating it. Through the art of renku, however, they learn more easily the ordinary meanings of words and their associations (Tamura, 2001). As renku therapy proceeds, the manner of the patient's linking is likely to change from simple word associations to contextual developments and to metaphorical extensions (Tamura \& Asano, 1997 as cited in Tamura, 2001). The benefits of poetry therapy in crisis intervention have been reported by Schwietert (2004), who verified that poetry helps to create a literal container where the various pieces of emotion can be held and, eventually, put back together again. Recently, Croom (2015) provided support for the claim that practicing poetry can positively contribute to one flourishing with greater psychological well-being by 
positively influencing their emotions, engagement or "flow" experiences, social relationships, sense of meaning or purpose in life, and personal accomplishments. However, besides poetry, we did not find any studies focusing solely on the benefits of other forms of creative literary writing, like fictional stories.

\subsection{Expressive writing: a non-literary method of writing}

Several empirical studies have demonstrated that writing about emotional experiences have significant mental health improvements (Pennebaker, 1997). These studies follow the Basic Writing Paradigm, which was first used by Pennebaker and Beal (1986) and it consists of a laboratorial trial that asks two or more experimental groups to write about assigned topics for 3 to 5 consecutive days, 15 to $30 \mathrm{~min}$ each day. The results demonstrate that writing about upsetting experiences, although painful in the days of writing, produces long-term improvements in mood and indicators of well-being compared with writing about control topics. The Paradigm has been replicated in numerous different experiments with and without clinical samples and with similar results. For instance, expressive writing has been used with positive effects in breast cancer survivors (Craft, Davis, \& Paulson, 2013), individuals with low initial depression (Baum \& Rude, 2013) and people with mood disorders (Baikie, Geerligs, \& Wilhelm, 2012). In a recent meta-analysis that evaluated the effects of expressive writing among adolescents in twenty-one independent studies, Travagin, Margola, and Revenson (2015) found that expressive writing tends to produce small yet significant improvements on adolescents' well-being.

It is demonstrated that most individuals are ready to disclose personal aspects of their lives when they are given the opportunity to do it (Pennebaker, 1997). For instance, in the study of Merrell, Hannah, Van Arsdale, Buman and Rice (2011) maladaptive perfectionist participants opted to share emotionally charged material when asked to write about their deepest feelings in spite of their personality traits and the impersonal nature of the study.

The effectiveness of expressive writing has been, anyway, challenged. In the experiment of Spera et al. (1994) with unemployed professionals, it was concluded that those who were assigned to write about thoughts and feelings about their job loss were reemployed more quickly although anger and hostility were prevalent in the writing sessions. Also, writing did not influence their motivation to seek employment, just influenced their attitudes to old jobs. In a study of Donnelly and Murray (1991) with clinical samples, a group of subjects told to write their traumatic experiences improved in the emotion resolution of trauma but, in spite of this, they showed an increased negative mood after each session. Another group was told to talk, rather than write, about a traumatic event with a psychotherapist and the 
increased negative mood after the sessions did not occur, suggesting a key role of the therapist. Also, in the empirical study of Bell-Pringle, Jurkovic and Pate (2004) college students were told to write about upsetting family events during four days, and in spite of an increase in negative mood and physical symptoms immediately after writing, they reported to feel better at posttest. These authors state that for individuals focusing on personally relevant and unprocessed events, even seemingly innocuous writing interventions may flood them with anxiety.

Therefore, just writing about negative events or emotions seems to result in an immediate increase in negative mood, and it may be especially arousing when these aspects had not been yet consciously processed.

One characteristic of the laboratorial empirical studies (e.g., Lestideau \& Lavallee, 2007; Pennebaker, 1997; Pennebaker, Francis \& Mayne, 1997) is their impersonal nature, nevertheless, they allow entering in the inner world of participants. Participants enter the studies without a previous knowledge of what they are going to do and they express emotions obeying the instructions given unexpectedly. It is a process that instructs individuals to make a description of personal contents and it proves that most of them are eager to disclose information. But still, there is a focus more on a descriptive writing mode rather than on an inventive mode that may transform the content and give it new meanings. We may assert that creativity can be somewhat impaired in this laboratory context. Also, the expressiveness (or the ability to put in words deep emotions) is not explored and stimulated as when this is made in the scope of a therapy or a workshop, when individual attention is given.

Writing about trauma or emotions is indeed being used in therapeutic settings for many years (e.g., Krantz \& Pennebaker, 1996; Pennebaker, 1997; Pennebaker \& Seagal, 1999), especially in the form of homework assignments or journaling but it is difficult to test the effectiveness of this task, since it is made as a complementary therapeutic activity. Clients are told to write at home about specific issues that are addressed in the counseling or psychotherapy sessions and can be then explored again in the following sessions. However, journaling is done under uncontrolled factors and can present some negative results. Wiitala and Dansereau (2004) stated that there is a lack of external ideas and insights in expressing writing, such as the ideas that would be available in a counseling situation, and individuals may remain stuck in their current patterns. Also, Baker and Mazza (2004) affirmed that encouraging clients to externalize cause more harm than benefit and Lestideau and Lavallee (2007) warned that health professionals must be cautious in recommending the use of introspective journals without the combination of expressive writing and planful problem solving. On the other hand, according to Riordan (1996), most counselors cite greater client involvement and increased therapeutic efficiency as advantages of prescribed. Moreover, Murphy and Mitchell (1998) considered the 
benefits of the e-mail as a therapy, stating that as the clients type a therapy e-mail, the written representation of their issues appears before them on the computer screen and this process that can enhance the externalization of problems. Besides, since writing is a recursive act, we typically read what we are writing and this in turn has the potential to impact on ourselves as we write, and impact on what we write next. From this viewpoint, the simple act of writing is therapeutic in itself.

\subsection{The need of a significant content: narrative writing in the context of the Basic}

\section{Writing Paradigm and its differences from creative writing}

The theory in which the writing paradigm is based states that individuals that conceal important psychological experiences are more inhibited, which contributes to health problems (Pennebaker, 1997). Krantz and Pennebaker (1996) underlined that, in order to have significant improvements, the traumatic experiences must be translated into language and not solely by another artistic non-verbal expression. Nevertheless, there is some evidence of the importance of turning the emotional written information into a significant content instead of just disclosing it verbally. According to data analysis of Pennebaker (1997), an increase in both causal and insight words over the course of writing is strongly associated with improved health, suggesting the importance of cognitive processing. Moreover, Pennebaker, Francis and Mayne (1997) verified that the linguistic expression of high rates of negative emotions, low rates of positive affect, or both, may not be conducive to physical or psychological health. They proposed that, in order to have health improvements, individuals participating in expressive writing must change the way they talk about a trauma across the days of writing and must alter their thinking patterns through cognitive processing. Also, in the experiment of Lestideau and Lavallee (2007), the participants were assigned either to an expressive writing task (exploring one's thoughts and feelings about a stressor) or to a planful writing task (developing plans to deal with the stressor) and it was verified that only planful writing had health benefits.

On the other hand, in an experiment by Baum and Rude (2013), individuals with relatively high levels of depression symptomatology failed to benefit from expressive writing in comparison with individuals with low to mild initial depressive symptoms. The authors suggested that individuals with high levels of depressive symptoms would have difficulty attaining a balanced perspective that may be required to emotional processing, which corroborates the importance of a more reflexive disclosure. Furthermore, Boals (2012) showed that meaning making during an expressive writing intervention can be beneficial if the participant writes about a highly distressing event. We found a single study that contradicts 
the importance of a significant content. Niles, Byrne, Haltom, Lieberman, Hur, and Stanton (2015) verified that more negative affect words and more discovery of meaning in expressive writing essays regarding stressful events predicted higher anxiety symptoms three months after writing. Hence, the authors highlighted the importance of self-affirmation and exposure as predictors of benefit from expressive writing.

According to Pennebaker (2004), individuals are often forced to label, structure, and organize the information in expressive writing tasks in ways they had never had to do and they must present the it in a linguistic structure to an ambiguous audience and to themselves. We may assert that creative writing takes this ability of linguistic structuring even further, since individuals organize the information not only to make it comprehensible and coherent but to have a meaning that transcends a literal description of facts.

Given the importance of structuring information into a coherent format and giving it a meaning in order to achieve therapeutic benefits, extensive research has proved that writing stressful events in a narrative structure predicts better health outputs than standard expressive writing (Smyth, True, \& Souto, 2001).

From a very long time narrative was understood as a way to make meaning of facts and experiences and hence it was used in folk traditions to transmit relevant information to the members of a group that can be easily assimilated. Actually, we remember the past more easily in the form of a narrative with the experiences being linked by causality.

We construct from an early age our own life story but it can be biased. Some people in therapy benefit from being helped in constructing a more adaptive life story or other alternative narratives of their lives in which they perceive themselves in a more positive way.

According to Pennebaker and Seagal (1999), a constructed story is a type of knowledge that helps to organize the emotional effects of an experience as well as the experience itself. In the same story we can talk both about the cause of the event and its many implications. Much as in any story there can be overarching themes, plots, and subplots-many of them arranged logically and/or hierarchically. Through this process, the many facets of the presumed single event are organized into a more coherent whole.

In fact, narrative therapists help individuals reframe their life experiences as stories, empowering the narrator to manipulate personal meanings, responses and reactions as a means of changing long-term consequences (Baker \& Mazza, 2004).

Also, narrative therapists can have an important role in helping old people in constructing a life review that reconsiders the past in a holistic way and gives new meanings to what they have experienced. In a recent study, Chippendale and Bear- 
Lehman (2012) found that life review writing was effective in decreasing depressive symptoms in older adults residing in senior residences.

Still regarding the potential benefits of narrative writing in the context of the Basic Writing Paradigm, Smyth et al. (2001) found in an empirical study that individuals asked to write in a narrative format about their thoughts and feelings related to the most traumatic event of their life reported less restriction of activity due to illness than individuals asked to write the same but in a fragmented format. The authors suggested that the mere expression of thoughts and feelings surrounding a traumatic experience may not be sufficient for health improvement and that narrative formation is necessary.

The ineffective therapeutic results showed in this study of the fragmented format can cast a doubt about the therapeutic virtues of typically fragmented forms of writing like poems, which in most cases have not a narrative support, have reduced causality links and a non linear grammatical or conceptual construction. Poems can be fragmented ideas or perceptions subtly linked by an esthetical sensibility and not necessarily organized to create an explicit meaning that make individuals have an insight over factual experiences. Meanings in the poems are often implicit through metaphors and images while in narratives there is a development of facts and feelings conducive to personal insights. Actually, poems may not expose descriptive experiences like in narratives and this concealing can make insights about such experiences more difficult. A recent study in Israel conducted by Barak and Leichtentritt (2016) found that the exercise of writing poems and editing them to reshape their meanings facilitated meaning-reconstruction for bereaved parents who were coping with a sudden traumatic loss of a child. This suggests that a subsequent editing intervention in the written poems may be beneficial in order to give them a new, more explicit meaning. Anyway, we did not find any empirical studies testing the therapeutic efficacy of writing fragmented poems versus narrative poems or stories.

On the other hand, instruction in narrative writing may be not positive. According to a study of Danoff-Burg, Mosher, Seawell and Agee (2010), in which the individuals in a standard expressive writing group rated their own essays as more personally meaningful and emotional than did the narrative writing group. The authors suggest that the narrative writing instructions may have resulted in greater focus on factual details relative to emotions. It is our opinion that giving specific writing instructions to express deep emotions may be felt as a constraint. Focusing in the causal logics of a story, trying to give a linear sequence to traumatic events that can even appear in the form of fragments or trying to give rational motives to overwhelming emotions may force individuals to a more intense cognitive processing and emotional detachment. 
We consider that expressive writing with narrative structure or life review has very different features from writing fictional creative stories. In expressive writing, individuals may give a new organization and meaning to past experiences, but this new meaning and the alternative interpretations to the past must be realistic, in accordance to what were the true experiences, so that the individuals can trust the new visions and identify themselves with what they are writing. A different situation occurs in creative writing, in which individuals can be encouraged to create stories that can be not related to them and they can invent the whole plot.

Also, although we did not find empirical studies that analyze the immediate emotional arousal after writing of poems or fiction, we can suggest that creative literary writing implies a transformation process of the information in order to make it significant and hence, it can offer a protective approach facing overwhelming issues and, in consequence, a protection against negative mood. Besides, creative writing is more like a longer and gradual process that may require more reflexive attention and deeper rational processing.

\section{Towards a creative writing program}

\subsection{Using expressive writing techniques in creative writing sessions with clinical populations}

We did not find any studies evaluating the benefits of the therapeutic writing of emotions or events versus literary writing in which the writers have more freedom to transform their emotions and decide if they are to be openly expressed or hired through metaphors or other stylistic figures. Actually, we did not find studies assessing the effectiveness of fictional writing, but only poetry.

Clinical effectiveness of the therapeutic uses of literature involves determining which mental health clients derive most benefit and which interventions are most effective for the achievement of specific goals (Cohen, 1994, as cited in McArdle \& Byrt, 2001). Actually, we think that if we want to use creative literary writing with a clinical population, we can learn from expressive writing studies since they test which writing characteristics predict better health outcomes or what are the moderator factors that influence better performances or outcomes. Therapeutic goals can be better achieved in creative writing if we analyze the controlled and randomized studies and adapt the writing methods that proved to be more beneficial. We can actually stimulate the creation of poems or fictional narratives using certain techniques of text construction or guide the participants 
to express themselves according to perspective takings that were shown as more therapeutic. We give some examples.

Pennebaker (1997) analyzed data from six writing studies and concluded that an increase in both causal (because, reason) and insight words (understand, realize) over the course of writing was strongly associated with improved health. Maybe we can stimulate the participants to construct stories based in strong causality links and with insightful moments in which there is a cognitive transformation.

Other text features in relation with health benefits were studied by Pennebaker, Mayne, and Francis (1997) that can help us to improve better creative writing programs. These authors indicate the existence of four linguistic categories in expressive writing associated with distress: high use of words suggestive of death, low use of past tense verbs, an increasing use of the number of positive emotion words from the first to the last day of writing, and a decreasing use of unique words. We recommend that when guiding creative writing sessions, professionals must pay attention if these characteristics are present in the texts that are being written and how can they be altered.

Regarding perspective taking and perspective switching in expressive writing, Seih, Chung, and Pennebaker (2011) concluded that individuals in a first-person perspective use more cognitive mechanism words as compared to the third-person perspective. This suggests that the first-person perspective also encourages the greatest degree of cognitive processing when narrating a negative emotional experience, which alerts us for the importance of the first-person perspective when aiming to make individuals productively reflect about their experiences, even through fictional writings.

In another study, East, Startup, Clifford and Schmidt (2010), studying the impact of writing tasks on eating disorders symptoms, verified that when individuals shift away from a first-person perspective and towards a "big picture" view-point, they become less emotionally engaged with the subject matter. The authors suggest that such "decentering" may be a useful therapeutic process but not for individuals with Anorexia Nervosa, who must be stimulated instead to engage with emotional experiences. From this perspective, we can affirm that creative writing workshops with this specific clinical group may focus on fictional narratives with a first-person perspective, enhancing at the same time inventiveness and emotional attachment with the character. Emotional personal experiences can be intertwined in a fictitious story, allowing the individuals to empathize with themselves at the same time they are able to imagine and create new pathways to deal with such experiences. Besides, Seigh et al. (2011) also verified that writing in the same perspective multiple times can evoke more emotions for a given writing topic, a technique that can be used to boost emotional engagement with individuals who detach from emotional 
experience like those with Anorexia Nervosa. Indeed, we can learn from empirical studies about the writing techniques that are the most appropriate to the necessities of specific clinical groups.

To know the moderator factors in expressive writing can be useful since we can boost certain features that mediate writing and better results. Poon and Danoff-Burg (2011) verified that individuals with higher mindfulness scores responded better to expressive writing. The authors consider that an individual who is mindful is more capable of paying attention to the writing process in the present moment and perhaps was more capable of paying attention to the experience of the actual event and to the internal and external events that followed. We suggest that this ability can be boosted at creative writing sessions, encouraging the participants to be attentive through specific mindful exercises that can be done in group before starting to write.

There are also documented ways of transforming therapeutic writing in a more enjoyable process. Wiitala and Dansereau (2004) verified that popular quotations can be used with therapeutic writing to make the process more interesting and enjoyable. Having the clients reflecting on inspirational quotations from successful individuals as they write about their personal difficulties proved to facilitate their engagement to the writing. We suggest that in creative writing sessions, the participants can also be provided with popular quotations and develop the ideas stated in the quotations through their original reflection or create stories or poems based on powerful and significant quotations. By this way, they are developing their creativity around content that proved to be helpful to many individuals. Quotations can be especially a powerful starting point for individuals that are more hesitating about the best manner to start writing.

\section{LIMITATIONS AND CONCLUSIONS}

The main limitation of this study is the fact that it is based in an unsystematic review that has a subjective nature and does not cover all the literature concerning the thematic. We opted to offer a broad perspective on the theme of writing as a therapy, selecting a number of references that could give an approximate answer to our research questions. However, our conclusions are preliminary and must be evaluated with caution. But at the same time, as far as we are concerned, our study is the first to appoint the problem concerning the lack of formal or theoretical distinctions between expressive and creative writing in the vast literature of therapeutic writing. We also point some valuable suggestions for future studies. 
Expressive and creative writing appear mixed in reviews as if both were subdivisions of the same concept of writing in the context of therapy. In fact, creative writing is a much more undefined concept and therapeutic practice, borrowed from an academic terminology in the Literature field. Concerning self-expression and imagination development, its benefits are not easy to assess as in expressive writing, which has a simple definition (to write about negative emotions and upsetting events). We suggest that in the future, researches and psychologists pay attention to these definitions before using writing as a therapeutic tool, and define their therapeutic goals based on the theoretical framing of the writing genre or type that will be used.

To create a meaning is an indispensable feature of creative literary writing. When people write a poem, for instance, they are organizing the information in certain ways so that a meaning can be achieved, even if only aesthetically. We assume that creative writing has the goal to transcend the mere expression of emotions, although the individuals who are instructed to write creatively may not be able or motivated to write more than a plain description of personal events. It is not easy to establish a boundary between emotion expression and giving a personal meaning to self-expression. Some studies tend to confirm the idea that giving a significant content or a narrative form to expressive writing texts will be more beneficial. This makes us think that writing fictional narratives may be an appealing practice to be tried in the therapeutic context. There are plenty of self-expressing literary genres (fictional stories and narratives, poetry) and each person may tend spontaneously to a specific genre or can be conducted to a certain genre by a therapist. We also did not find any studies that make comparative evaluations between the benefits of the different creative genres. We can assume that any creative task is therapeutic on its own but we lack an evaluation and a comparison of the benefits of the different creative writing tasks done under different instructions. Also, there are no established ways of assessing qualitatively or quantitatively the therapeutic benefits of creative writing. We found several studies of poetry therapy done with clinical samples and its assessment has a much more significant qualitative nature.

Our study has practical implications regarding the elaboration of creative writing programs. We proposed some examples of already tested expressive writing techniques and methods that can be useful to adapt in such programs in the future.

\section{BIBLIOGRAPHY}

Baker, K. C., \& Mazza N. (2004). The healing power of writing: Applying the expressive/ creative component of poetry therapy. Journal of Poetry Therapy, 17(3), 141-154. doi:10.1080/08893670412331311352 
Baikie, K. A., Geerligs, L., \& Wilhelm, K. (2012). Expressive writing and positive writing for participants with mood disorders: An online randomized controlled trial. Journal of Affective Disorders, 136(3), 310-319. doi: 10.1016/j.jad.2011.11.032

Barak, A., \& Leichtentritt, R. D. (2016). Creative writing after traumatic loss: Towards a generative writing approach. British Journal of Social Work, 10. doi: 10.1093/bjsw/bcw030

Baum, E. S., \& Rude, S. S. (2013). Acceptance-enhanced expressive writing prevents symptoms in participants with low initial depression. Cognitive Therapy and Research, 37(1), 35-42. doi: 10.1007/s10608-012-9435-x

Bell-Pringle, V. J., Jurkovic, G. J., \& Pate, J. L. (2004). Writing about upsetting family events: A therapy analog study. Journal of Contemporary Psychotherapy, 34(4), 341-349. doi: 10.1007/ s10879-004-2528-4

Boals, A. (2012). The use of meaning making in expressive writing: When meaning is beneficial. Journal of Social and Clinical Psychology, 31(4), 393-409. doi: 10.1521/jscp.2012.31.4.393

Chippendale, T., \& Bear-Lehman, J. (2012). Effect of life review writing on depressive symptoms in older adults: A randomized controlled trial. American Journal of Occupational Therapy, 66, 438-446. doi: 10.5014/ajot.2012.004291

Craft, M. A., Davis, G. J., \& Paulson, R. M. (2013). Expressive writing in early breast cancer survivors. Journal of Advanced Nursing, 69(2), 305-315. doi: 10.1111/j.1365-2648.2012.06008.x

Croom, A. M. (2015). The practice of poetry and the psychology of well-being. Journal of Poetry Therapy, 28(1), 21-41. doi: 10.1080/08893675.2015.980133

Danoff-Burg, S., Mosher, C. E., Seawell, A. H., \& Agee J. D. (2010). Does narrative writing instruction enhance the benefits of expressive writing? Anxiety, Stress \& Coping, 23(3), 341-352. doi: $10.1080 \% 2 \mathrm{~F} 10615800903191137$

Donnelly, D., \& Murray, E. (1991). Cognitive and emotional changes in written essays and therapy interviews. Journal of Social and Clinical Psychology, 10(3), 334-350. doi: 10.1521/jscp.1991.10.3.334

East, P., Startup, H., Clifford R., \& Schmidt, U. (2010). Expressive writing and eating disorder features: A preliminary trial in a student sample of the impact of three writing tasks on eating disorder symptoms and associated cognitive, affective and interpersonal factors. European Eating Disorders Review, 18, 180-196. doi: 10.1002/erv.978

Fallahi Khoshknab, F., Asayesh, H., Qorbani, M., Fadaei, F., \& Rahmani Anaraki, H. (2016). The effect of poetry therapy group on communicational skills of schizophrenic patient. Journal of Nursing and Midwifery, 13(11), 919-927.

Fair, C. D., Connor, L., Albright, J., Wise, E., \& Jones, K. (2012). "I’m positive, I have something to say": Assessing the impact of a creative writing group for adolescents living with HIV. The Arts in Psychotherapy, 39, 383-389. doi: 10.1016/j.aip.2012.06.010

Grant, M. J., \& Booth, A. (2009). A typology of reviews: an analysis of 14 review types and associated methodologies. Health Information \& Libraries Journal, 26(2), 91-108. doi: 10.1111/j.1471$-1842.2009 .00848 . x$.

Heims, S. (2011). State of poetry research (review). The Arts in Psychotherapy, 38, 1-8. doi: 10.1016/j. aip.2010.09.006

Houlding, S., \& Holland, P. (1988). Contributions of a poetry writing group to the treatment of severely disturbed psychiatric inpatients. Clinical Social Work Journal, 16(2), 194-200. doi: 10.1007/BF00754450

King, R., Neilsen, P., \& White, E. (2013). Creative writing in recovery from severe mental illness. International Journal of Mental Health Nursing, 22, 444-452. doi: 10.1111/j.1447-0349.2012.00891.x 
Krantz, A., \& Pennebaker, J. W. (1996). Bodily versus written expression of traumatic experience. Manuscript submitted for publication.

Lestideau, O. T., \& Lavallee, L. F. (2007). Structured writing about current stressors: The benefits of developing plans. Psychology and Health, 22(6), 659-676. doi: 10.1080/14768320601176089

Mazza, N. F., \& Hayton, C. J. (2013). Poetry therapy: An investigation of a multidimensional clinical model. The Arts in Psychotherapy, 40, 53-60. doi: 10.1016/j.aip.2012.10.002

McArdle, S., \& Byrt, R. (2001). Fiction, poetry and mental health: Expressive and therapeutic uses of literature. Journal of Psychiatric and Mental Health Nursing, 8, 517-524.

Merrell, R. S., Hannah, D. J., Van Arsdale, A. C., Buman, M. P., \& Rice, K. G. (2011). Emergent themes in the writing of perfectionists: A qualitative study. Psychotherapy Research, 21(5), 510-24. doi: 10.1080/10503307.2011.587468

Miller, D. (1978). Poetry therapy with psychotic patients. Journal of Contemporary Psychotherapy, 9(2), 135-138. doi: 10.1007/BF01815982

Murphy, L. J., \& Mitchell, D. L. (1998). When writing helps to heal: E-mail as therapy. British Journal of Guidance \& Counseling, 26(1), 21-32. doi: 10.1080/03069889808253835

Niles, A. N., Byrne Haltom, K. E., Lieberman, M. D., Hur, C., \& Stanton, A. L. (2015). Writing content predicts benefit from written expressive disclosure: Evidence for repeated exposure and self-affirmation. Cognition and Emotion, 3, 1-17. doi: 10.1080/02699931.2014.995598

Nysse, O. P., Taylor, S. J., Wong, G., Steed, E., Bourke, L. Lord, J., ... Meads, C. (2016). Does therapeutic writing help people with long-term conditions? Systematic review, realist synthesis and economic considerations. Health Technology Assessment, 20(27), 1-367. doi: 10.3310/hta20270

Pennebaker, J. W. (1997). Writing about emotional experiences as a therapeutic process. Psychological Science, 8(3), 162-166. doi: 10.1111/j.1467-9280.1997.tb00403.x

Pennebaker, J. W. (2004). Theories, therapies, and taxpayers: On the complexities of the expressive writing paradigm. Clinical Psychology: Science and Practice, 11(2), 138-142. doi: 10.1093/clipsy.bph063

Pennebaker, J. W., \& Beal, S. K. (1986). Confronting a traumatic event: Toward an understanding of inhibition and disease. Journal of Abnormal Psychology, 95, 274-281. doi: 10.1037//0021-843X.95.3.274

Pennebaker, J. W., Mayne, T., \& Francis, M. E. (1997). Linguistic predictors of adaptive bereavement. Journal of Personality and Social Psychology, 72(4), 863-871.

Pennebaker, J. W., \& Seagal, J. D. (1999). Forming a story: The health benefits of narrative. Journal of Clinical Psychology, 55(10), 1243-1254. doi: 10.1002/(SICI)1097-4679(199910)55:10\%3C1243::AIDJCLP6\%3E3.0.CO;2-N

Poon, A., \& Danoff-Burg, S. (2011). Mindfulness as a moderator in expressive writing. Journal of Clinical Psychology, 67(9), 881-895. doi: 10.1002/jclp.20810

Resende, A. C. (2008). Esquizofrenia e criatividade artística. III Mostra de Pesquisa da Pós-Graduação - Faculdade de Psicologia, PUCRS.

Riordan, R. J. (1996). Scriptotherapy: Therapeutic writing as a counseling adjunct. Journal of Counseling \& Development, 74(3), 263-269. doi: 10.1002/j.1556-6676.1996.tb01863.x

Ruddy, R., \& Milnes, D. (2005). Art therapy for schizophrenia or schizophrenia-like illnesses. Cochrane Database of Systematic Reviews, 4, CD003728.

Schwietert, J. A. (2004). The use of poetry therapy in crisis intervention and short-term treatment: Two case studies. Journal of Poetry Therapy, 17(4), 189-198.

Seih, Y., Chung, C. K., \& Pennebaker, J. W. (2011). Experimental manipulations of perspective taking and perspective switching in expressive writing. Cognition and Emotion, 25(5), 926-938. doi: $10.1080 / 02699931.2010 .512123$ 
Smyth, J., True, N., \& Souto, J. (2001). Effects of writing about traumatic experiences: The necessity for narrative structuring. Journal of Social and Clinical Psychology, 20(2), 161-172. doi: 10.1521/ jscp.20.2.161.22266

Spera, S., Buhrfeind, E., \& Pennebaker, J. (1994). Expressive writing and coping with job loss. Academy of Management Journal, 37(3), 722-733. doi: 10.2307/256708

Tamura, H. (2001). Poetry therapy for schizophrenia: A linguistic psychotherapeutic model of renku (linked poetry). The Arts in Psychotherapy, 28, 319-328.

Travagin, G., Margola, D., \& Revenson, T. A. (2015). How effective are expressive writing interventions for adolescents? A meta-analytic review. Clinical Psychology Review, 36, 42-55. doi: 10.1016/j.cpr.2015.01.003

Wiitala, W. L., \& Dansereau, D. F. (2004). Using popular quotations to enhance therapeutic writing. Journal of College Counseling, 7, 187-191. doi: 10.1002/j.2161-1882.2004.tb00250.x 